\title{
Isolation of Microalgae from Mediterranean Seawater and Production of Lipids in the Cultivated Species
}

\author{
Imane Haoujar 1,2,*(D), Francesco Cacciola ${ }^{3, *(\mathbb{D})}$, Manuel Manchado ${ }^{4} \mathbb{D}$, Jamal Abrini $^{1}$, \\ Mohammed Haoujar ${ }^{5}$, Kamal Chebbaki ${ }^{2}$, Marianna Oteri ${ }^{6}{ }^{\mathbb{D}}$, Francesca Rigano ${ }^{7} \mathbb{D}$, \\ Domenica Mangraviti ${ }^{7}$, Luigi Mondello ${ }^{7,8,9,10} \mathbb{D}$, Adil Essafi ${ }^{11}$, Hicham Chairi ${ }^{12}(\mathbb{D}$ and \\ Nadia Skali Senhaji ${ }^{1}$
}

1 Laboratory of Biotechnology and Applied Microbiology, Department of Biology, Faculty of Sciences of Tetouan, Abdelmalek Essaadi University, 93000 Tetouan, Morocco; abrinij@hotmail.com (J.A.); senhajin@hotmail.com (N.S.S.)

2 Specialized Center in Zootechnics and Marine Aquaculture Engineering, National Institute of Fisheries Research, 93200 M'Diq, Morocco; chebbakikamal@yahoo.fr

3 Department of Biomedical, Dental, Morphological and Functional Imaging Sciences, University of Messina, 98125 Messina, Italy

4 IFAPA El Toruño, 11500 El Puerto de Santa Maria, Spain; manuel.manchado@juntadeandalucia.es

5 IAV Hassan II, Madinat Al Irfane 6202 Instituts, 10101 Rabat, Morocco; haoujartopographie@gmail.com

6 Department of Veterinary Sciences, University of Messina, Viale Annunziata, 98168 Messina, Italy; moteri@unime.it

7 Department of Chemical, Biological, Pharmaceutical and Environmental Sciences, University of Messina, 98168 Messina, Italy; frigano@unime.it (F.R.); dmangraviti@unime.it (D.M.); lmondello@unime.it (L.M.)

8 Chromaleont s.r.l., c/o Department of Chemical, Biological, Pharmaceutical and Environmental Sciences, University of Messina, 98168 Messina, Italy

9 Department of Sciences and Technologies for Human and Environment, University Campus Bio-Medico of Rome, 00128 Rome, Italy

10 BeSep s.r.l., c/o Department of Chemical, Biological, Pharmaceutical and Environmental Sciences, University of Messina, 98168 Messina, Italy

11 National Aquaculture Development Agency, 10100 Rabat, Morocco; adil.essafi@yahoo.com

12 Laboratory of Biological Engineering, Agri-Food and Aquaculture, Department of Biology, Faculty poly-disciplinary of Larache, Abdelmalek Essaadi University, 92000 Larache, Morocco; hicham.chairi@yahoo.fr

* Correspondence: imane.haoujar2015@gmail.com (I.H.); cacciolaf@unime.it (F.C.); Tel.: +21-262-422-8056 (I.H.); +39-090-676-6570 (F.C.)

Received: 7 October 2020; Accepted: 30 October 2020; Published: 4 November 2020

\begin{abstract}
Isolation and identification of novel microalgae strains with high lipid productivity is one of the most important research topics to have emerged recently. However, practical production processes will probably require the use of local strains adapted to commanding climatic conditions. The present manuscript describes the isolation of 96 microalgae strains from seawater located in Bay M'diq, Morocco. Four strains were identified using the 18S rDNA and morphological identification through microscopic examination. The biomass and lipid productivity were compared and showed good results for Nannochloris sp. (15.93 mg/L/day). The lipid content in the four species, namely Nannochloropsis gaditana, Nannochloris sp., Phaedactylum tricornutum and Tetraselmis suecica, was carried out by high performance liquid chromatography coupled to mass spectrometry (HPLC-MS) highlighting the identification of up to 77 compounds.
\end{abstract}

Keywords: microalgae; isolation; identification; lipid productivity; HPLC-MS 


\section{Introduction}

Aquatic microalgae are photosynthetic microorganisms that live with a variety of other species and meet different ecological requirements [1]. They represent one of the first forms of life on earth, and they have been found in oceans for more than 3 billion years since terrestrial environmental components were installed [2,3]. Fifty thousand microalgae species with diverse groups like Cyanobacteria, prokaryotic and eukaryotic microalgae have been discovered in oceans and freshwater lakes, ponds, and rivers around the world, however, only thirty thousand of them have been analyzed [1]. Thanks to their biological property, microalgae can be used as a new source of compounds in several biotechnological applications, including wastewater treatment [4], biodiesel production [5], and as supplements for human and animal dietary $[6,7]$.

A large amount of funding has recently been invested to select the best species of microalgae with high bioactive metabolites [8]. Microalgae represent several sources of bioactive compounds, such as polyphenols, carotenoids, polysaccharides, omega-3, fatty acids, and polyunsaturated fatty acids (PUFA) [9-12]. The lipid concentrations in microalgae are between $20 \%$ and $70 \%$, and the fatty acid composition in algal cells is highly dependent on genetic and phenotypic agents, including environmental and culture conditions [13]. Large scale lipid production will command the use of competitive species that are easy to grow and adapt to local environmental conditions. Isolating strains of microalgae with rapid growth, high intrinsic lipid content, and high biomass productivities is a primary necessity [14-16]. The quantity of total lipids in the form of glycolipid, phospholipid, and neutral lipid is varied considerably among and within groups of microalgae [6]. Many prior studies have identified the percent of omega-3 fatty acids between 30 and $40 \%$ of their total fatty acids in several species of microalgae like Nannochloropsis sp. (EPA), Schizochytrium limacinum (DHA), and Phaeodactylum tricornutum [17].

As a consequence, microalgae have great potential in the human diet as supplements for the treatment of physiological aberrations, prevention management, and used as synthetic dietary supplements to providing sustainable natural resources [18].

The isolation and identification of algal species from a natural environment is a well-established procedure. Each species has different growing conditions, including several regulations and key physic-chemical factors controlling growth and development such as temperature, $\mathrm{pH}$, salinity, and silicate for diatoms $[19,20]$.

The main objective of the present study was to evaluate the effect of the dilution technique and agar plate to separate and isolate different microalgae from Bay M'diq, Morocco. Biomass productivity, lipid productivity, and lipids content of some isolated microalgae were evaluated. Moreover, the 18SrDNA encoding gene of the microalgal isolates was sequenced to confirm the identification of the isolates. The ultra-high performance liquid chromatography coupled to mass spectrometry (UHPLC-MS) has been successfully used for the analysis of several lipid classes such as triacylglycerols (TGs), glycolipids, and phospholipids [21].Ahigh chromatographic resolution was achieved by serially coupling two narrow-bore partially porous columns [22]. A reversed-phase stationary phase, viz.octadecylsilica (C18), was used in order to obtain a good separation of lipids, according to their different hydrophobicity. As for MS detection, a single quadrupole was used as an analyzer and the atmospheric pressure chemical ionization (APCI) interface was used as an ion source. The APCI, different from the most common electrospray (ESI), is able to generate some in-source fragmentation, useful for structure elucidation, especially when a single quadrupole is employed as the MS analyzer and tandem MS experiments cannot be carried out [23-25].

\section{Materials and Methods}

\subsection{Sampling and Isolation}

Different species of microalgae were collected from seawater at Bay of M'diq, which is located in the north-western part of Morocco, between Sebta $\left(35^{\circ} 54^{\prime} \mathrm{N}, 5^{\circ} 1^{\prime} 10^{\prime \prime} \mathrm{W}\right)$ and Capo Negro $\left(35^{\circ} 40^{\prime} \mathrm{N}\right.$, 
$16^{\prime} 40^{\prime \prime}$ W). Samples were selected from three collection sites: (i) proximity to a fish farm of the bay; (ii) off the coast of Martil, and (iii) at Kabila Port (Figure 1). A volume of $1 \mathrm{~L}$ of seawater sample was taken using clean bottles at a depth of $0.5 \mathrm{~m}$ and then stored in cool boxes for transportation to the laboratory.

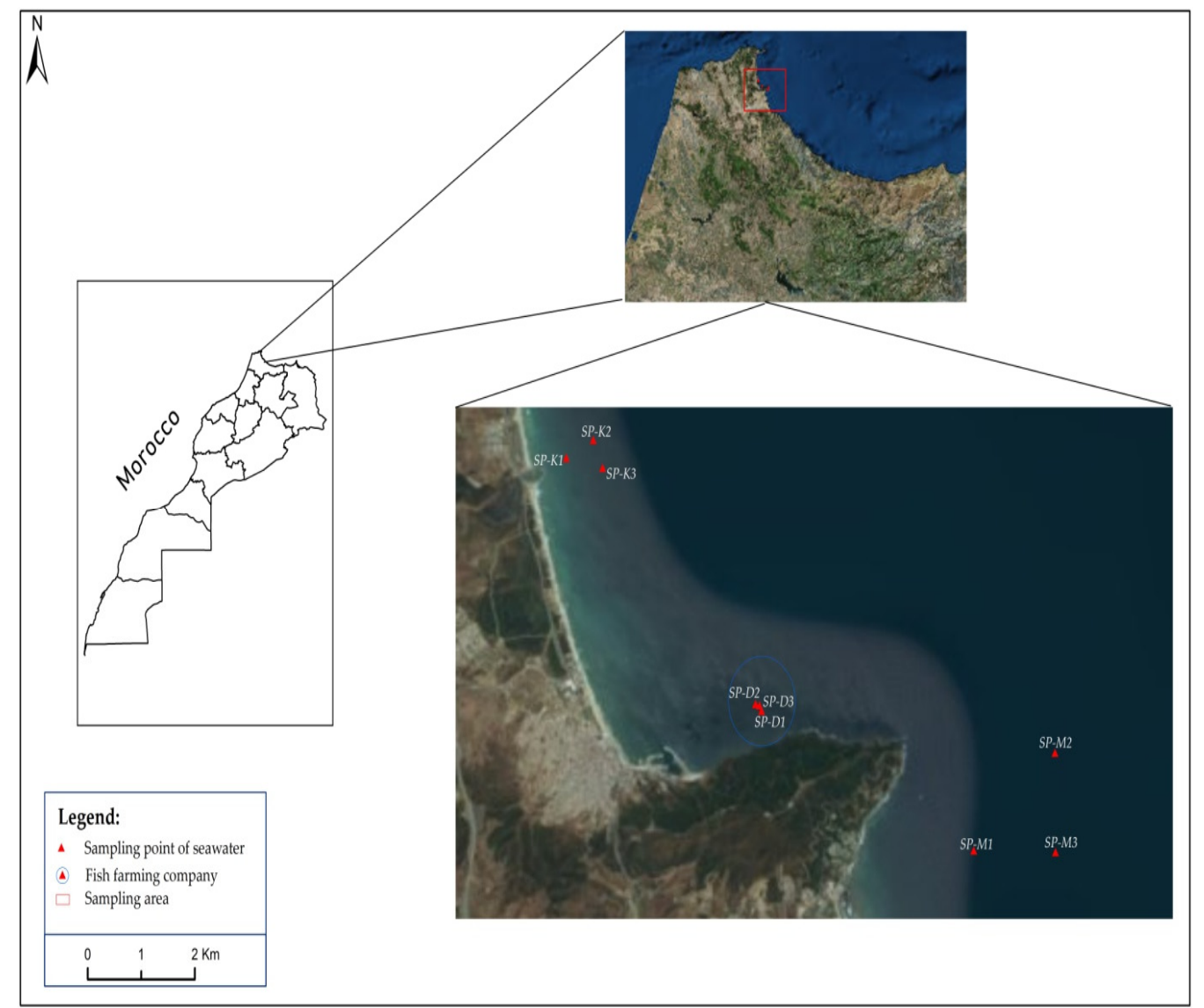

Figure 1. Distribution map of sampling points in M'diq Bay, Morocco.

Seawater samples were taken from December 2017 to February 2018 in a regular manner with constant frequencies with nine samples per month.

Once in the laboratory, the samples are purified using two methods; they were inoculated on an agar plate and in a liquid medium (Guillard F/2) that contained: $\mathrm{NaNO}_{3} 8.82 \times 10^{-4} \mathrm{M} ; \mathrm{NaH}_{2} \mathrm{PO}_{4} \cdot \mathrm{H}_{2} \mathrm{O}$ $3.62 \times 10^{-5} \mathrm{M} ; \mathrm{Na}_{2} \mathrm{SiO}_{3} \cdot 9 \mathrm{H}_{2} \mathrm{O} 1.06 \times 10^{-4} \mathrm{M} ; \mathrm{FeCl}_{3} \cdot 6 \mathrm{H}_{2} \mathrm{O} 1.17 \times 10^{-5} \mathrm{M} ; \mathrm{Na}_{2}$ EDTA $2 \mathrm{H}_{2} \mathrm{O} 1.17 \times 10^{-5} \mathrm{M}$; $\mathrm{MnCl}_{2} \cdot 4 \mathrm{H}_{2} \mathrm{O} 9.10 \times 10^{-7} \mathrm{M} ; \mathrm{ZnSO}_{4} \cdot 7 \mathrm{H}_{2} \mathrm{O} 7.65 \times 10^{-8} \mathrm{M} ; \mathrm{CoCl}_{2} \cdot 6 \mathrm{H}_{2} \mathrm{O} 4.20 \times 10^{-8} \mathrm{M} ; \mathrm{CuSO}_{4} \cdot 5 \mathrm{H}_{2} \mathrm{O} 3.93$ $\times 10^{-8} \mathrm{M} ; \mathrm{Na}_{2} \mathrm{MoO}_{4} \cdot 2 \mathrm{H}_{2} \mathrm{O} 2.60 \times 10^{-8} \mathrm{M}$; Thiamin $\mathrm{HCl}$ (Vit. B1) $2.96 \times 10^{-7} \mathrm{M}$; Biotin (Vit. H) $2.05 \times$ $10^{-9} \mathrm{M}$; and Cyanocobalamin (Vit. B12) $3.69 \times 10^{-10} \mathrm{M}[26]$.

For those isolated on an agar plate, the first group of samples was filtered through a series of membranes of decreasing mesh $(33,20$, and $0.45 \mu \mathrm{m})$. Each membrane was directly plated on agar plates containing $\mathrm{F} / 2$ medium solidified with $1.5 \%$ of agar and incubated in a light chamber at two temperatures $\left(20\right.$ and $26^{\circ} \mathrm{C}$ ). After growth, different colonies were transferred to tubes of $8 \mathrm{~mL}$ [27]. However, the second group of samples was isolated by successive dilutions, starting with $1 \mathrm{~mL}$ of sample to $10 \mathrm{~mL}$ of $\mathrm{F} / 2$ medium in order to transfer only one cell into a test tube, thereby establishing a single-cell isolate $[28,29]$. This procedure of dilution was repeated with serial dilutions from $10^{-2}$ to $10^{-10}$ until obtained unicellular tubes medium [30,31] (Figure 2). 


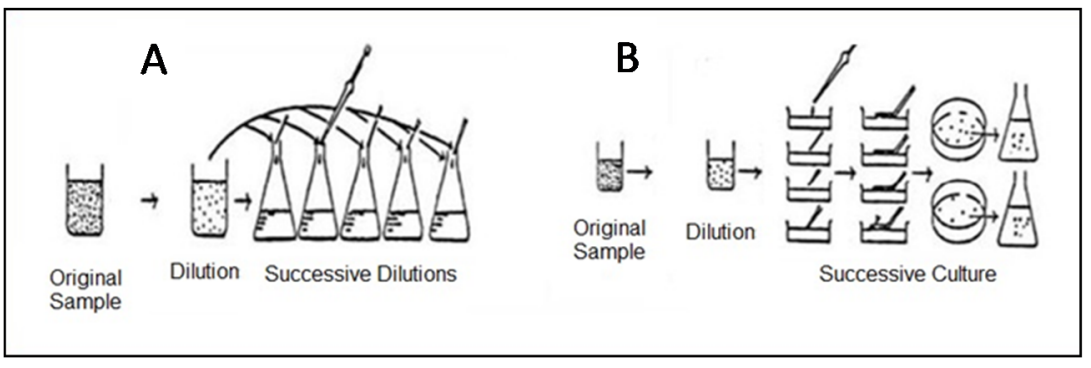

Figure 2. Method of cell isolation with (A) successive dilution, and (B) inoculation on an agar plate.

During the isolation process, the $\mathrm{F} / 2$ medium using in this experiment was divided into two groups; one with and the other one without silicate, to select only strains that required this nutrient. All strains incubated at two temperatures $\left(20\right.$ and $\left.26^{\circ} \mathrm{C}\right)$ to evaluate the effect of temperature on cell growth; All cultivations were alimented with atmospheric $\mathrm{CO}_{2}$. The light was provided by warm white fluorescent bulbs at $25 \mathrm{~W} / \mathrm{m}^{2}$ and operated on a light/dark cycle of 12/12 h.

After cell growth, all tubes were inoculated by transferring to $125 \mathrm{~mL}$ flasks add by $70 \mathrm{~mL}$ of $\mathrm{F} / 2$ medium, then incubated with a photoperiod of $18 / 6 \mathrm{~h}$.

\subsection{Strain Identification}

The morphological identification of different isolated strains was carried out by microscopic observation. At the end, for molecular identification, DNA was extracted using $1030 \mathrm{mg}$ of microalgal dried biomass.

Samples were homogenized using the FastDNA kit for $40 \mathrm{~s}$ at speed setting 5 in the Fastprep FG120 instrument (Bio101, Inc., Vista, CA, USA) but using the reagents of the ISOLATE II Genomic DNA Kit (Bioline) kit following the manufacture's protocols. DNA was quantified spectrophotometrically using the Nanodrop ND8000.

PCR amplifications were carried out using the Platinum Multiplex Master Mix (Thermofisher) in a $25 \mu \mathrm{L}$ final volume containing $20 \mathrm{ng}$ DNA, $300 \mathrm{nM}$ each of specific forward and reverse primers, and $12.5 \mu \mathrm{L}$ of Enzyme Premix (Thermofisher). The amplification protocol used was as follows: initial $11 \mathrm{~min}$ denaturation and enzyme activation at $95^{\circ} \mathrm{C}, 30$ cycles of $20 \mathrm{~s}$ at $95^{\circ} \mathrm{C}, 1 \mathrm{~min}$ at $56^{\circ} \mathrm{C}\left(60^{\circ} \mathrm{C}\right)$ and $2 \mathrm{~min}$ at $72{ }^{\circ} \mathrm{C}$ and final extension step of $10 \mathrm{~min}$ at $72^{\circ} \mathrm{C}$. The $18 \mathrm{~S}$ rDNA primers used were $18 \mathrm{SF}$ and euk516R $[32,33]$ and for plastidic gene ribulose-1,5-bisphosphate carboxylase/oxygenase large subunit (rbcl) TetraRBCL_F and R [34] (Table 1). The PCR products were electrophoresed on a 2\% agarose gel after staining with ethidium bromide and visualized via ultraviolet transillumination. Following the PCR reaction, free dNTPs and primers were removed using the PCR product purification kit (Marlingen Bioscience, Ijamsville, MD, USA). The cycle sequencing was performed with the Bigdye Terminator v3.1 kit (Applied Biosystems, Foster City, CA, USA). All sequencing reactions were performed according to the manufacturer's instructions using the ABI3130 Genetic Analyzer (Applied Biosystems). The $18 \mathrm{~S}$ rDNA and rbcl sequences were used in a BLAST search in order to retrieve the most closely related sequences.

Table 1. List of primers used in this study, including the primer sequences, amplicon length, annealing temperature, and the sequencing success rate for four strains tested.

\begin{tabular}{ccccc}
\hline Primer & Molecular Marker & Sequence & Annealing $\mathbf{T}^{\circ}$ & Reference \\
\hline 18SF & $18 \mathrm{~S}$ rDNA & AACCTGGTTGATYCTGCCAG & $56^{\circ} \mathrm{C}, 60^{\circ} \mathrm{C}$ & {$[32]$} \\
Euk516r & $18 \mathrm{~S}$ rDNA & ACCAGACTTGCCCTCC & $56{ }^{\circ} \mathrm{C}, 60^{\circ} \mathrm{C}$ & {$[33]$} \\
Tetra_rbcL_F & rbcl & GKACTTGGACAACTGTATGGACKGATGGT & $56{ }^{\circ} \mathrm{C}$ & IFAPA \\
Tetra_rbcL_R & rbcL & GRTCTTTTTCWACRTAAGCATCACGCATTA & $56{ }^{\circ} \mathrm{C}$ & IFAPA \\
\hline
\end{tabular}




\subsection{Lipid Analysis}

Extraction and Measurement of Lipid Contents

The biomass was harvested at a stationary phase growth (after 15 days of cultivation) by centrifugation (at $4400 \mathrm{rpm}$ for $15 \mathrm{~min}$ ) and lyophilization for $12 \mathrm{~h}$ [30].

The evaluation of lipids fraction from selected microalgae was carried out using the Folch method [35]: $200 \mathrm{mg}$ of lyophilized biomass was extracted in triplicate for $30 \mathrm{~min}$ with a chloroform/methanol $(2: 1, v / v)$ mixture at $25{ }^{\circ} \mathrm{C}$ under agitation. The procedure was repeated three times. The organic phase was centrifuged at $3000 \mathrm{RCF}$ for $15 \mathrm{~min}$. The sample was then filtered using Whatman $\mathrm{N}^{\circ} 1$ filter paper in a funnel, collected in a flask, and evaporated at $40^{\circ} \mathrm{C}$.

The productivity of biomass was calculated from the following equation: $\mathrm{PB}(\mathrm{mg} / \mathrm{L} / \mathrm{day})=\mathrm{CB} / \mathrm{T}$; where $\mathrm{CB}(\mathrm{mg} / \mathrm{L})$ was the concentration of biomass from the beginning until the end of the cultivation, and $\mathrm{T}$ was the duration of cultivation (15 days).

In addition, the lipid productivity of each sample was determined by Li et al.'s (2008) equation: $\mathrm{PL}=\mathrm{LT} /(\mathrm{V}$ culture $\times \mathrm{T})$ and $\%$ lipids $=(\mathrm{LT} /(\mathrm{CB} \times \mathrm{V}$ culture $)) \times 100$; where $\mathrm{PL}$ was the lipid productivity $(\mathrm{mg} / \mathrm{L} /$ day), LT was the total lipids (mg), $\mathrm{T}$ was the duration of the experiment, and $\mathrm{V}$ culture was the volume [36,37].

\subsection{HPLC Analysis}

HPLC-MS analyses of the lipid contents from the obtained residue dissolved in chloroform were performed on a Shimadzu Nexera LC-30A system (Shimadzu, Kyoto, Italy), consisting of a CBM-20A controller, two LC-30AD dual-plunger parallel flow pumps, a DGU-20A5 degasser, a CTO-20A oven, and a SIL-30AC autosampler. The HPLC system was coupled with an LCMS-2020 single quadrupole mass spectrometer equipped with an APCI interface (Shimadzu, Kyoto, Japan). Chromatographic separation was achieved on two serially coupled Ascentis Express C18 columns $100 \times 2.1 \mathrm{~mm} \mathrm{~L} \times \mathrm{I}$.D., $2.7 \mu$ m d.p. (Merck Life Science, Merck KGaA, Darmstadt, Germany), and the injection volume was $10 \mu \mathrm{L}$. A linear gradient of ACN/water $(80: 20, v / v)(\mathrm{A})$ and IPA (B) was run at a mobile phase flow rate of $500 \mu \mathrm{L} / \mathrm{min}$ : $0-105 \mathrm{~min}, 0-50 \% \mathrm{~B}$ (hold for $5 \mathrm{~min}$ ). MS parameters were as follows: $\mathrm{m} / \mathrm{z}$ range, 150-1200; ion accumulation time, $0.6 \mathrm{~s}$; nebulizing gas $\left(\mathrm{N}_{2}\right)$ flow rate, during gas flow rate, $2 \mathrm{~L} / \mathrm{min}$; detector voltage, $4.5 \mathrm{kV}$; interface temperature, $450{ }^{\circ} \mathrm{C}$; $\mathrm{CDL}$ temperature, $250{ }^{\circ} \mathrm{C}$; block temperature, $300{ }^{\circ} \mathrm{C}$.

\subsection{Statistical Analysis}

All statistical tests were performed using SPSS statistical software (SPSS software version 16.0 IBM). The different medians of results were analyzed by one-way ANOVA with a significance level of $p<0.05$ and compared by Tukey's TSD method [38].

\section{Results and Discussion}

\subsection{Isolation of Native Microalgae}

The sampling and isolation procedures used in this experiment were successful in establishing a culture collection of ninety-six local microalgae. The microscopic analysis showed that the majority were green algae (Chlorophyta), followed by diatoms and finally cyanobacteria with the lowest number. Sixty-four microalgae were isolated using successive dilution and thirty-two microalgae by inoculation on agar plate (Figure 3A). Following the analysis of variance, ANOVA one-way showed that the difference was insignificant $(p>0.05)$ between the two isolation processes. The two processes used in this experiment turned out to be reproducible to purify microalgal cells. The use of agar plate for isolation was the preferred method for Coccoid and the most soil algae since it represents an axenic culture for direct established without further treatment $[28,31]$. 


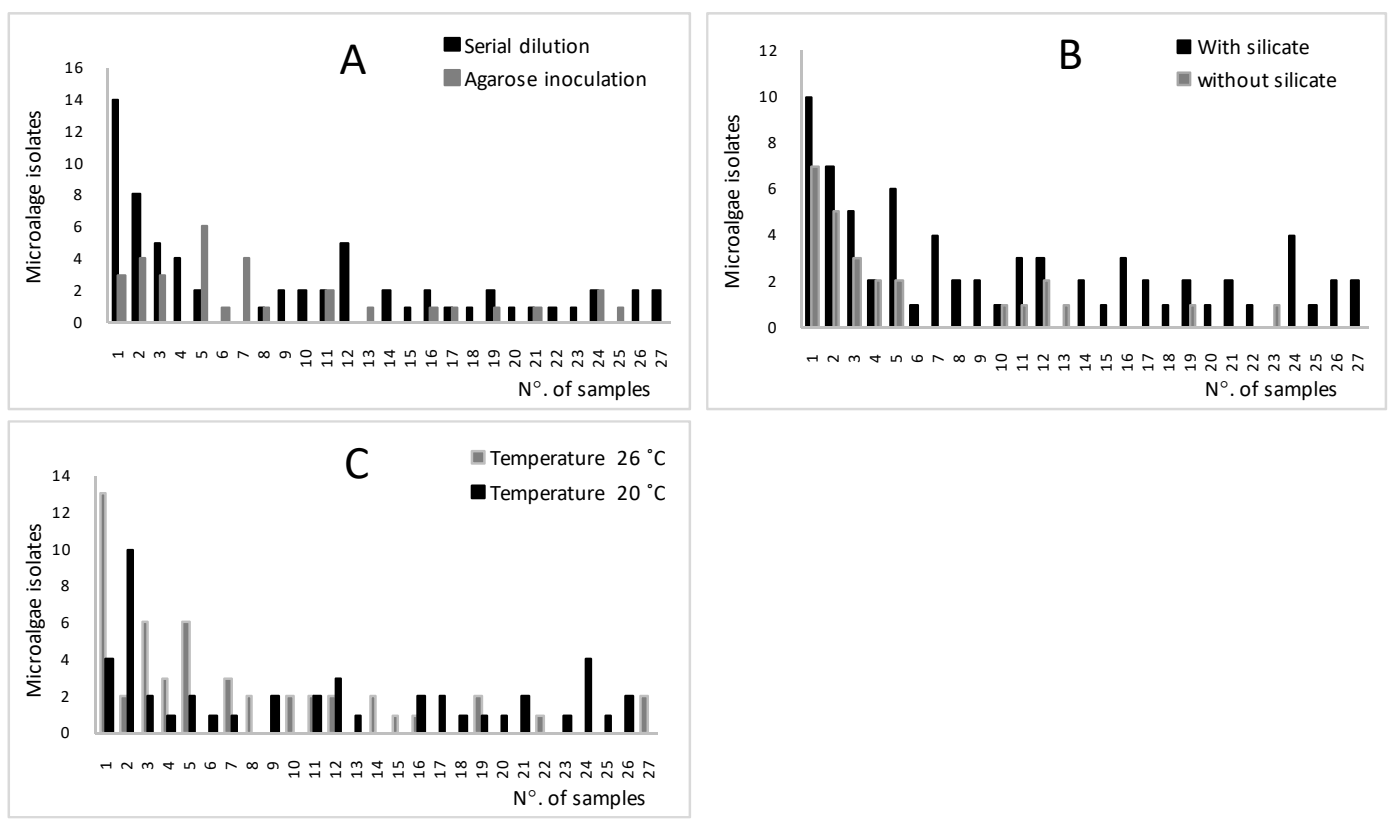

Figure 3. Strains curves for isolated microalgae using successive dilution, (A) inoculating on an agar plate, (B) in $\mathrm{F} / 2$ with or without silicate and (C) incubation at $20^{\circ} \mathrm{C}$ and $26{ }^{\circ} \mathrm{C}$.

Seventy and twenty-six species were isolated using F/2 culture medium with and without silicate, respectively. The highest number of species were isolated in the culture medium with silicate. The highest number of isolated species was obtained in December 2017 using F/2 medium added by silicate (Figure 3B). In addition, the statistical analysis using One-way ANOVA (Table 2) revealed that the difference between the two groups was highly significant $(p<0.01)$. Therefore, the silicate nutrient added to the $\mathrm{F} / 2$ medium had a great impact in regulating the cell growth [39].

Table 2. ANOVA-test statistics values of each isolated microalgae.

\begin{tabular}{cccccc}
\hline \multicolumn{2}{c}{ One-Factor ANOVA } & & & & \\
\hline \multirow{2}{*}{ Parameter } & Source & df & Sum of Squares & F & P \\
\hline \multirow{3}{*}{ Silicate } & Inter-group & 1 & 35.85 & 9.07 & $0.004^{*}$ \\
& Intra-group & 52 & 205.48 & & \\
& Total & 53 & 241.33 & & \\
\hline
\end{tabular}

* The average difference is significant at the 0.05 level.

Following previous results, the highest number of species, isolated using a culture medium added by silicate, may be explained by the dominance of diatoms. Moreover, Egge and Aksnes (1992) confirmed that diatom strains represent $70 \%$ of the cell numbers by using a concentration of $2 \mathrm{mM}$ silicate [40].

Temperature is one of the key criteria for the growth of microalgae and directly acts on the linear and exponential growth of microalgae species [41,42]. In this experiment, fifty species and forty-six strains were isolated at $26{ }^{\circ} \mathrm{C}$ and $22{ }^{\circ} \mathrm{C}$, respectively (Figure 3C). Our results were confirmed by Ahlgren's study [41], which showed that the range of temperatures between $16-27^{\circ} \mathrm{C}$ was determined as optimal for algal growth rates. Consequently, the species of microalgae were flexible and adaptable with the temperatures tested and able to produce several physiological and biochemical reactions [41-44]. The insignificant difference $(p=0.823)$ between the temperatures confirmed the possibility of growth cells at $26^{\circ} \mathrm{C}$ and $22{ }^{\circ} \mathrm{C}$. 


\subsection{Molecular Identification of Native Microalgae}

Four species of microalgae collected from different seawater habitats were identified by microscopic morphological examination based on the form of their cells (Figure 4). Subsequently, two molecular markers were considered to ensure their taxonomic group (Figure 5). The isolated microalgae 1, 4, 5, and 7 were closely related to Nannochloropsis gaditana Lubián (MN625926), Phaeodactylum tricornutum Bohlin (MN625939), Nannochloris sp. KMMCC161 Naumann (MN625923) and Tetraselmis suecica Butcher (MN625941) deposited in the NCBI database under GenBank with mentioned accession numbers in parentheses.

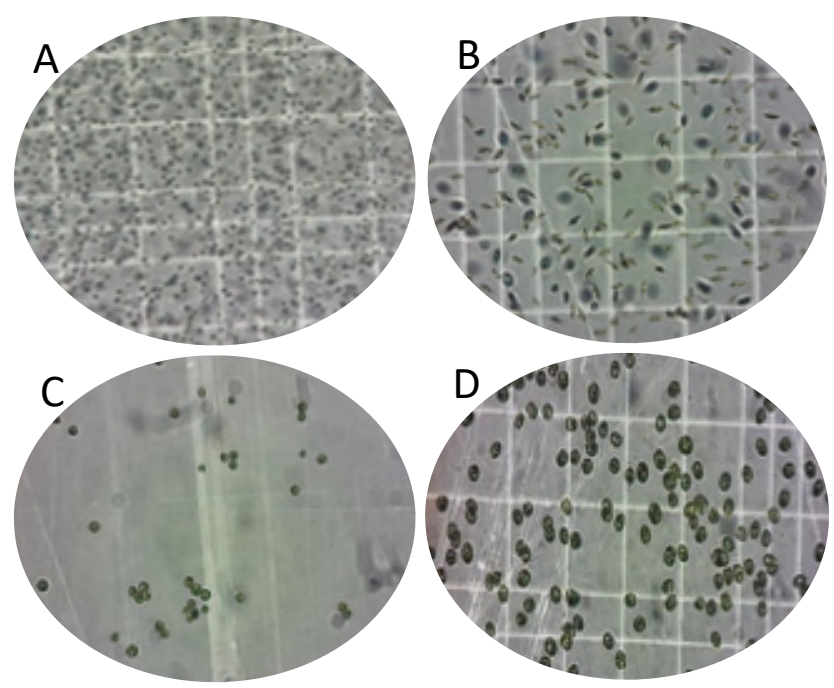

Figure 4. Light microscopic observation of isolated microalgae: (A) Nannochloropsis gaditana, (B) Phaeodactylum tricornutum, (C) Nannochloris sp., and (D) Tetraselmis suecica.

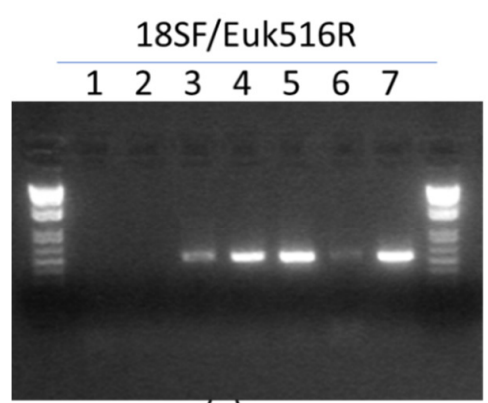

(a)

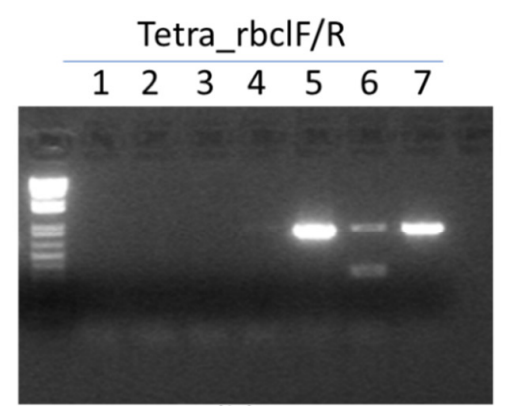

(b)

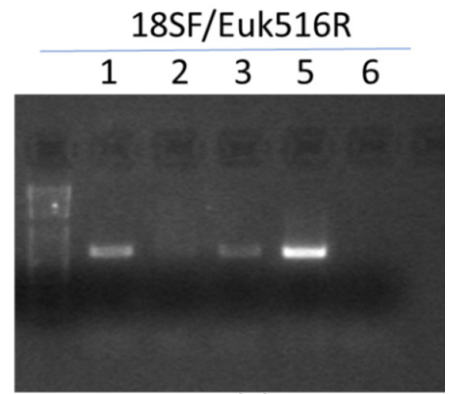

(c)

Figure 5. Molecular identification of selected microalgae. 1 to 7 : number of strains. $(\mathbf{a}, \mathbf{b})$ : annealing $\mathrm{T}^{\circ}$ of $56^{\circ} \mathrm{C}$. (c): annealing $\mathrm{T}^{\circ}$ of $60^{\circ} \mathrm{C}$.

\subsection{Biomass and Lipid Productivity}

One of the key criteria to select microalgae for lipid applications is high intracellular lipid content [45]. Growth and biomass productivity are the most studied parameters to determine the suitable microalgae able to cultivate and using for commercial algal production. In our experiment, a significant difference in lipid levels was determined. The highest biomass productivity was reported in N. gaditana then, Nannochloris sp., P. tricornutum, and T. suecica with 97.09, 96.92, 24.47, and $12.54 \mathrm{mg} / \mathrm{L} /$ day, respectively. The highest and the lowest levels of lipid productivity were respectively obtained for Nannochloris sp., and T. suecica species that were measured to be 15.93 and $0.92 \mathrm{mg} / \mathrm{L} /$ day (Table 3). Growth rate and biomass productivity directly affect the lipid content [46]; lower biomass productivity can negatively affect productivity even if the lipid content is high [47]. 
Table 3. Biomass and Lipid Content of Selected Microalgae Species in Batch Culture (400 mL) after 15 Aays of Growth in F/2 Medium.

\begin{tabular}{|c|c|c|c|c|c|c|}
\hline Species & $\begin{array}{l}\text { Weight of dry } \\
\text { biomass } \\
(\mathrm{mg} / 400 \mathrm{~mL})\end{array}$ & $\begin{array}{c}\text { Concentration } \\
\text { of biomass } \\
(\mathrm{mg} / \mathrm{L})\end{array}$ & $\begin{array}{l}\text { Productivity } \\
\text { of biomass } \\
\text { (mg/L/day) }\end{array}$ & $\begin{array}{l}\text { Total lipids } \\
(\mathrm{mg} / 400 \mathrm{~mL})\end{array}$ & $\begin{array}{l}\text { Lipids } \\
(\%)\end{array}$ & $\begin{array}{c}\text { Lipid } \\
\text { productivity } \\
\text { (mg/L/day) }\end{array}$ \\
\hline P. tricornutum & $146.82 \pm 1.1^{b}$ & $367.05 \pm 0.15^{b}$ & $24.47 \pm 0.15^{b}$ & $27.85 \pm 0.1^{b}$ & $47.43 \pm 0.68^{d}$ & $4.64 \pm 0.1^{b}$ \\
\hline T. suecica & $75.25 \pm 0.2^{\mathrm{a}}$ & $188.13 \pm 0.9^{a}$ & $12.54 \pm 0.03^{\mathrm{a}}$ & $5.50 \pm 0.04^{\mathrm{a}}$ & $18.28 \pm 0.7^{\mathrm{a}}$ & $0.92 \pm 0.02^{a}$ \\
\hline N. gaditana & $582.53 \pm 0.15^{c}$ & $1456.33 \pm 1.43^{c}$ & $97.09 \pm 0.68^{c}$ & $33.29 \pm 0.8^{c}$ & $14.28 \pm 0.32^{b}$ & $5.55 \pm 0.01^{b}$ \\
\hline Nannochloris sp., & $581.52 \pm 1.4^{c}$ & $1453.8 \pm 1.3^{c}$ & $96.92 \pm 0.72^{c}$ & $95.58 \pm 0.81^{d}$ & $41.08 \pm 0.26^{c}$ & $15.93 \pm 0.9^{c}$ \\
\hline
\end{tabular}

Values are medians of three repetitions \pm standard deviation. The different letters $(a, b, c, d)$ indicate significant differences between species (Tukey HSD, $p<0.05$ ).

The total lipid contents of the microalgae cultured under our experimental growth conditions ranged from $18.28 \%$ to $47.43 \%$ of their dry weight. P. tricornutum and Nannochloris sp., showed the highest lipid content at $47.43 \%$ and $41.08 \%$, while T. suecica and $N$. gaditana have the lowest lipid content at 18.28 and $14.28 \%$, respectively. Dunaliella tertiolecta species isolated from Morocco by El Arroussi et al. (2017) had a lipid content of $21 \%$, which confirmed that the lipid productivity was greatly affected by cultivation conditions; salinity, light intensity, temperature, $\mathrm{pH}$ of medium, and composition of culture medium used [21,45]. In addition, many studies have confirmed that the limited concentration of nitrogen favored the accumulation of lipids in Chlorella species [46-49].

\subsection{HPLC Analysis of Lipid Contents}

LC-MS analysis was applied to separate and identify the lipid fraction in the four isolated microalgae. The separation of lipids classes reported in Figure 6 confirmed a good separation of neutral and polar lipids. Table 4 lists the details of different lipid classes tentatively identified in all algal samples confirmed by literature data $[23,25,50,51]$. The identification was carried out with the support of LIPID MAPS Lipidomics Gateway (https://www.lipidmaps.org/), which allowed the identification of a total of 77 compounds in all the selected microalgae species. The lipid composition was constituted basically by mono-, di- and triglycerides (MG, DG, and TG), sulfoquinovosyldiacylglicerols (SQDG), mono- and digalactosyldiacylglycerols (MGDG and DGDG), phospholipids (PLs) and carotenoids (xanthophylls and chlorophylls) in the four microalgal isolates. The lipid fraction of microalgae can also include glycolipids, sterols, carotenoids, chlorophylls, and phospholipids. Algae can synthesize fatty acids to product their membrane lipids in the optimal growth conditions, which constitute phospholipids and glycolipids. However, in conditions of stress, algae alter their biosynthetic pathways and generate neutral lipids to store energy in the form of TGs [52-54]. Notably TGs are significantly produced by the environmental microalgal isolates as demonstrated by the relatively intense peaks of the chromatograms. In fact, intense peaks were identified in N. gaditana and Nannochloris sp. with TGs C17:0LAr/C17:0OEp-OOP/SLnP and in T. suecica with TGs (OOP/PPoG/PoOL), while in P. tricornutum, glycolipids SQDG (34:4) occurred as the highest peaks. However, previous studies have demonstrated that some Tetraselmis sp., Nannochloris sp., Phaeodactylum tricornutum, and Nannochloropsis gaditana species can produce more lipids under certain stressed conditions $[32,47,49,50]$.

Table 4. Compounds tentatively identified in the lipid fraction.

\begin{tabular}{|c|c|c|c|c|c|c|c|}
\hline Peak & Compounds & {$[\mathrm{M}+\mathrm{H}]^{+}$} & {$[\mathrm{M}+\mathrm{H}]^{-}$} & $\begin{array}{c}N . \\
\text { gaditana }\end{array}$ & $\begin{array}{c}T . \\
\text { suecica }\end{array}$ & $\begin{array}{c}P . \\
\text { tricornutum }\end{array}$ & $\begin{array}{c}\text { Nannochloris } \\
\text { sp., }\end{array}$ \\
\hline 1 & MG 20:0 & 369.5 & & + & - & - & - \\
\hline 2 & MG 16:0 & 313.2 & & + & - & - & - \\
\hline 3 & DG $(36: 4)$ & 599.5 & & + & + & - & - \\
\hline 4 & PG (34:3) & & 762.3 & - & - & + & - \\
\hline 5 & DG (34:2) & 617.3 & & + & - & - & - \\
\hline 6 & SQDG (32:1) & 549.5 & 791.5 & - & - & + & - \\
\hline 7 & DG $(36: 2)$ & 603.4 & & - & + & - & - \\
\hline 8 & DG (32:1) & 549.5 & & - & - & + & - \\
\hline 9 & Neoxanthin & 601.7 & & + & - & - & - \\
\hline 10 & DG (32:0) & 551.4 & & - & - & - & + \\
\hline
\end{tabular}


Table 4. Cont.

\begin{tabular}{|c|c|c|c|c|c|c|c|}
\hline Peak & Compounds & {$[\mathrm{M}+\mathrm{H}]^{+}$} & {$[\mathrm{M}+\mathrm{H}]^{-}$} & $\begin{array}{c}N . \\
\text { gaditana }\end{array}$ & $\begin{array}{c}T . \\
\text { suecica }\end{array}$ & $\begin{array}{c}P . \\
\text { tricornutum }\end{array}$ & $\begin{array}{c}\text { Nannochloris } \\
\text { sp., }\end{array}$ \\
\hline 11 & PG (34:4) & & 741.4 & - & + & - & + \\
\hline 12 & PG (34:3) & & 762.3 & - & + & - & - \\
\hline 13 & MGDG (34:5) & 766.5 & & + & - & - & - \\
\hline 14 & DG (32:5) & 583.6 & & - & + & - & - \\
\hline 15 & TG (ArArO/SArEp) & 928.5 & 909.7 & + & - & - & - \\
\hline 16 & PE $(34: 3)$ & & 762.4 & + & - & - & - \\
\hline 17 & DG (32:4) & 585.5 & & - & - & - & + \\
\hline 18 & DGDG (36:6) & 954.6 & 935.4 & + & - & - & - \\
\hline 19 & SQDG (34:4) & & 813.6 & - & - & + & - \\
\hline 20 & DGDG (34:4) & 930.6 & & - & - & - & + \\
\hline 21 & DGDG (36:6) & 954.6 & 935.4 & - & - & + & - \\
\hline 22 & Antheraxanthin & 585.9 & & - & + & - & - \\
\hline 23 & PC (36:1) & 788.5 & 812.7 & + & - & + & - \\
\hline 24 & SQDG (34:0) & & 821.5 & + & - & - & - \\
\hline 25 & PI (36:4) & & 857.5 & + & - & - & - \\
\hline 26 & trans-Lutein & 569.9 & & - & - & - & + \\
\hline 27 & TG (C20:3LL) & 907.6 & & + & - & - & - \\
\hline 28 & SQDG (34:3) & & 815.5 & - & - & + & - \\
\hline 29 & TG (20:3LL) & 907.5 & & - & - & + & - \\
\hline 30 & PG (34:1) & & 766.3 & - & + & - & - \\
\hline 31 & PC (36:3) & & 784.5 & + & + & - & - \\
\hline 32 & MGDG (36:5) & 794.5 & & + & - & - & - \\
\hline 33 & MGDG (34:6) & 764.5 & & + & - & - & - \\
\hline 34 & MGDG (36:6) & 792.5 & & - & - & + & - \\
\hline 35 & PG (36:5) & & 786.5 & - & - & - & + \\
\hline 36 & PG (34:1) & & 766.3 & - & - & + & - \\
\hline 37 & TG (SOAr) & 908.6 & & + & - & - & - \\
\hline 38 & PE (39:6) & & 776.5 & + & - & - & - \\
\hline 39 & PE $(38: 3)$ & & 768.5 & + & - & - & - \\
\hline 40 & PG (36:4) & & 788.4 & - & - & - & + \\
\hline 41 & DGDG (34:2) & 934.5 & 915.6 & - & + & - & + \\
\hline 42 & PC (38:3) & 814.5 & & + & - & - & - \\
\hline 43 & PG (34:0) & & 768.5 & - & - & + & - \\
\hline 44 & SQDG (34:1) & & 819.4 & - & - & + & - \\
\hline 45 & PC (38:5) & 808.8 & & - & + & - & - \\
\hline 46 & DGDG (36:1) & 964.7 & & - & + & - & - \\
\hline 47 & hydroxychlorophyllide b & 645.1 & & - & + & - & - \\
\hline 48 & PC $(33: 2)$ & & 744.5 & + & - & - & - \\
\hline 49 & PE (38:5) & & 764.5 & + & - & - & - \\
\hline 50 & b-carotene & 537.9 & & + & - & - & - \\
\hline 51 & TG (LnLnPo) & 849.4 & & - & - & - & + \\
\hline 52 & MGDG (34:2) & 772.5 & 753.6 & - & - & - & + \\
\hline 53 & TG (LnGG/OGLn/SGAr) & 936.8 & & - & + & - & - \\
\hline 54 & PC (33:1)-PC (O-16:0/18:1) & 746.5 & & - & - & + & - \\
\hline 55 & TG (GEpD) & 981.5 & & - & + & - & - \\
\hline 56 & PI (40:8) & & 905.5 & - & + & - & - \\
\hline 57 & TG (GLL) & 909.5 & & - & + & - & - \\
\hline 58 & TG (ArArAr) & 950.5 & & - & + & - & - \\
\hline 59 & PC (32:2) & & 730.5 & + & - & - & - \\
\hline 60 & TG (OLC18:4) & 877.5 & & - & - & + & - \\
\hline 61 & $\begin{array}{c}\text { TG } \\
\text { (C17:0LAr/C17:0OEp-OOP/SLnP) }\end{array}$ & $893.6-859.8$ & & + & - & - & - \\
\hline 62 & TG (EpC18:4C18:4) & 893.4 & & - & + & - & - \\
\hline 63 & TG (GLL/LLnA/OLnG) & 909.5 & & - & - & + & - \\
\hline 64 & TG (EpEpL) & 923.5 & & - & - & + & - \\
\hline 65 & PI (38:1) & & 892.6 & - & - & + & - \\
\hline 66 & TG (SSS) & 891.4 & & - & - & + & - \\
\hline 67 & Anhydroeschscholtzxanthin & & 529.3 & - & + & - & + \\
\hline 68 & TG (C18:4C18:4Ep) & 893.6 & & + & - & - & + \\
\hline 69 & TG (OOP/PPoG/PoOL) & 925.6 & & - & + & - & - \\
\hline 70 & PC (44:5) & & 890.3 & - & - & + & - \\
\hline 71 & TG (ЕpC18:4C18:4) & 893.6 & & - & - & + & - \\
\hline 72 & TG (ArArLn/OEpEp/ArEpL) & 925.6 & & - & + & - & - \\
\hline 73 & TG (SOO/SSL/PLA) & 887.5 & & + & - & - & - \\
\hline 74 & TG (MMDh) & 823.5 & & - & + & - & - \\
\hline 75 & TG (SOO/SSL/PLA) & 887.5 & & - & - & + & - \\
\hline 76 & TG (OOMo/LnLn18:4) & 871.4 & & + & - & - & - \\
\hline 77 & Pheophytin a $\left(\mathrm{C}_{55} \mathrm{H}_{74} \mathrm{~N}_{405}\right)$ & 871.4 & 870.6 & + & - & + & + \\
\hline
\end{tabular}

Note: MG, monoglyceride; DG, diglyceride; TG, triglyceride; SQDG, sulfoquinovosyldiacylglicerol; MGDG, monogalactosyldiacylglycerol; DGDG, digalactosyldiacylglycerol; $\mathrm{PG}$, phosphatidylglycerol; $\mathrm{PE}$, phosphatidylethanolamine; PC, phosphatidylcholine; PI, phosphatidylinositol. $\mathrm{M}=\mathrm{C} 14: 0 ; \mathrm{Mo}=\mathrm{C} 14: 1 ; \mathrm{P}=\mathrm{C} 16: 0 ; \mathrm{Po}=\mathrm{C} 16: 1 ; \mathrm{S}=\mathrm{C} 18: 0 ; \mathrm{O}=\mathrm{C}$ 18:1. $\mathrm{L}=\mathrm{C} 18: 2 ; \mathrm{Ln}=\mathrm{C} 18: 3 ; \mathrm{A}=\mathrm{C} 20: 0 ; 0020 \mathrm{G}=\mathrm{C} 20: 1 ; \mathrm{Ar}=\mathrm{C} 20: 4 ; \mathrm{Ep}=\mathrm{C} 20: 5 ; \mathrm{B}=\mathrm{C} 22: 0 ; \mathrm{D}=\mathrm{C} 22: 5 ; \mathrm{Dh}=\mathrm{C} 22: 6$. 

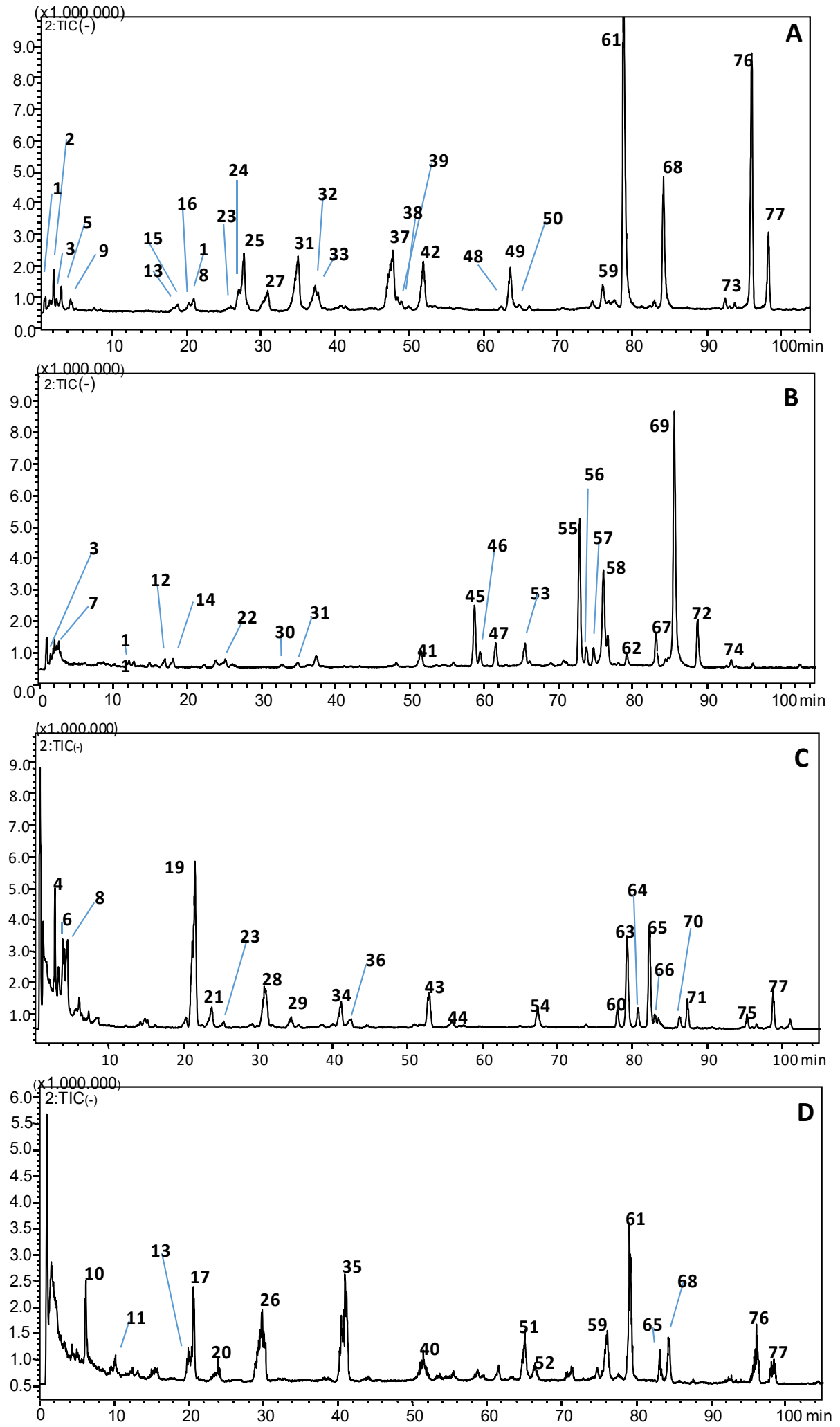

Figure 6. Base peak chromatograms of lipids extract of four isolated microalgae. (A) N. gaditana; (B); T. suecica; (C) P. tricornutum; (D) Nannochloris sp. For experimental conditions, see the text. For peak identification, see Table 4. 
The comprehensive lipid profiles obtained for the four strains showed their higher potential of glycolipids, phospholipids, and triacylglycerols to be an ideal source of food additives, ingredient for functional foods, and nutraceuticals applications [31,51].

\section{Conclusions}

This study reports the identification of four strains of microalgae from Moroccan Mediterranean seawater, which might be suitable for lipid production to be potentially used as supplement aquatic and animal feed rich in PUFA and other food products with higher omega-3 fatty acids content. In particular, the data from this study showed that Nannochloris sp., had the highest lipid productivity of $15.93 \mathrm{mg} / \mathrm{L} /$ day. Furthermore, the HPLC-MS analysis showed their highest content of lipidic molecules (77 in total) and might be useful as dietary supplements or biofuels feedstock.

Author Contributions: Conceptualization, F.C. and M.M.; methodology, K.C.; software, H.C. and A.E.; validation, F.R. and M.M.; formal analysis, D.M. and M.O., F.R.; investigation, M.H.; writing-original draft preparation, I.H.; writing-review and editing, F.C.; supervision, N.S.S., L.M., F.C., and J.A. All authors have read and agreed to the published version of the manuscript.

Funding: This research received no external funding.

Acknowledgments: The authors are thankful to Shimadzu and MerckLife Science Corporations for their continuous support.

Conflicts of Interest: No potential conflict of interest was reported by the authors.

\section{References}

1. Richmond, A. Handbook of Microalgal Culture: Biotechnology and Applied Phycology; Blackwell Science: Oxford, UK, 2004; p. 289; ISBN 978-1-4051-2832-2.

2. Falkowski, P.G. The Evolution of Modern Eukaryotic Phytoplankton. Science 2004, 305, 354-360. [CrossRef] [PubMed]

3. Sathasivam, R.; Radhakrishnan, R.; Hashem, A.; Abd Allah, E.F. Microalgae metabolites: A rich source for food and medicine. Saudi J. Biol. Sci. 2017, 26, 709-722. [CrossRef] [PubMed]

4. Craggs, R.J.; Adey, W.H.; Jenson, K.R.; John, M.S.S.; Green, F.B.; Oswald, W.J. Phosphorus removal from wastewater using an algal turf scrubber. Water Sci. Technol. 1996, 33, 191-198. [CrossRef]

5. Demirbas, A.; Demirbas, M.F. Importance of algae oil as a source of biodiesel. Energy Convers. Manag. 2011, 52, 163-170. [CrossRef]

6. Enzing, C.; Ploeg, M.; Barbosa, M.; Sijtsma, L. Microalgae-based products for the food and feed sector: An outlook for Europe. JRC Sci. Policy Rep. 2014, 19-37.

7. Spolaore, P.; Joannis-Cassan, C.; Duran, E.; Isambert, A. Commercial applications of microalgae. J. Biosci. Bioeng. 2006, 101, 87-96. [CrossRef]

8. Hu, G.-P.; Yuan, J.; Sun, L.; She, Z.-G.; Wu, J.-H.; Lan, X.-J.; Zhu, X.; Lin, Y.-C.; Chen, S.-P. Statistical research on marine natural products based on data obtained between 1985 and 2008. Mar. Drugs. 2011, 9, 514-525. [CrossRef]

9. De JesusRaposo, M.F.; De Morais, R.M.S.C.; de Morais, B.; Miranda, A.M. Bioactivity and applications of sulphated polysaccharides from marine microalgae. Mar. Drugs. 2013, 11, 233-252.

10. Peng, J.; Yuan, J.-P.; Wu, C.-F.; Wang, J.-H. Fucoxanthin, a marine carotenoid present in brown seaweeds and diatoms: Metabolism and bioactivities relevant to human health. Mar. Drugs. 2011, 9, 1806-1828. [CrossRef] [PubMed]

11. Haimeur, A.; Ulmann, L.; Mimouni, V.; Guéno, F.; Pineau-Vincent, F.; Meskini, N.; Tremblin, G. The role of Odontellaaurita, a marine diatom rich in EPA, as a dietary supplement in dyslipidemia, platelet function and oxidative stress in high-fat fed rats. Lipids Health Dis. 2012, 11, 147. [CrossRef]

12. Goiris, K.; Muylaert, K.; Fraeye, I.; Foubert, I.; De Brabanter, J.; De Cooman, L. Antioxidant potential of microalgae in relation to their phenolic and carotenoid content. J. Appl. Phycol. 2012, 24, 1477-1486. [CrossRef]

13. Nuzzo, G.; Gallo, C.; d'Ippolito, G.; Cutignano, A.; Sardo, A.; Fontana, A. Composition and quantitation of microalgal lipids by ERETIC 1H NMR method. Mar. Drugs. 2013, 11, 3742-3753. [CrossRef] 
14. Hannon, M.; Gimpel, J.; Tran, M.; Rasala, B.; Mayfield, S. Biofuels from algae: Challenges and potential. Biofuels 2010, 1, 763-784. [CrossRef]

15. Elliott, L.G.; Feehan, C.; Laurens, L.M.; Pienkos, P.T.; Darzins, A.; Posewitz, M.C. Establishment of a bioenergy-focused microalgal culture collection. Algal Res. 2012, 1, 102-113. [CrossRef]

16. Abdelaziz, A.E.M.; Leite, G.B.; Belhaj, M.A.; Hallenbeck, P.C. Screening microalgae native to Quebec for wastewater treatment and biodiesel production. Bioresour. Technol. 2014, 157, 140-148. [CrossRef]

17. Poblete-Castro, I.; Escapa, I.F.; Jäger, C.; Puchalka, J.; Lam, C.M.C.; Schomburg, D.; Prieto, M.A.; dos Santos, V.A.M. The metabolic response of P. putida KT2442 producing high levels of polyhydroxyalkanoate under single-and multiple-nutrient-limited growth: Highlights from a multi-level omics approach. Microb. Cell Factor. 2012, 11, 34. [CrossRef] [PubMed]

18. Beetul, K.; Gopeechund, A.; Kaullysing, D.; Mattan-Moorgawa, S.; Puchooa, D.; Bhagooli, R. Challenges and Opportunities in the Present Era of Marine Algal Applications; InTechOpen: London, UK, 2016; pp. 237-276.

19. Judd, S.; van den Broeke, L.J.P.; Shurair, M.; Kuti, Y.; Znad, H. Algal remediation of $\mathrm{CO}_{2}$ and nutrient discharges: A review. Water Res. 2015, 87, 356-366. [CrossRef] [PubMed]

20. Ismail, N.M.; Ismail, A.F.; Mustafa, A.; Matsuura, T.; Soga, T.; Nagata, K.; Asaka, T. Qualitative and quantitative analysis of intercalated and exfoliated silicate layers in asymmetric polyethersulfone/cloisite15A ${ }^{\circledR}$ mixed matrix membrane for $\mathrm{CO}_{2} / \mathrm{CH}_{4}$ separation. Chem. Eng. J. 2015, 268, 371-383. [CrossRef]

21. Guschina, I.A.; Harwood, J.L. Lipids and lipid metabolism in eukaryotic algae. Prog. Lipid Res. 2006, 45, 160-186. [CrossRef] [PubMed]

22. Ragonese, C.; Tedone, L.; Beccaria, M.; Torre, G.; Cichello, F.; Cacciola, F.; Dugo, P.; Mondello, L. Characterisation of lipid fraction of marine macroalgae by means of chromatography techniques coupled to mass spectrometry. Food Chem. 2014, 145, 932-940. [CrossRef]

23. He, H.; Rodgers, R.P.; Marshall, A.G.; Hsu, C.S. Algae polar lipids characterized by online liquid chromatography coupled with hybrid linear quadrupole ion trap/fourier transform ion cyclotron resonance mass spectrometry. Energy Fuels. 2011, 25, 4770-4775. [CrossRef]

24. Rigano, F.; Oteri, M.; Russo, M.; Dugo, P.; Mondello, L. Proposal of a Linear Retention Index System for Improving Identification Reliability of Triacylglycerol Profiles in Lipid Samples by Liquid Chromatography Methods. Anal. Chem. 2018, 90, 3313-3320. [CrossRef] [PubMed]

25. Beccaria, M.; Inferrera, V.; Rigano, F.; Gorynski, K.; Purcaro, G.; Pawliszyn, J.; Dugo, P.; Mondello, L. Highly informative multiclass profiling of lipids by ultra-high performance liquid chromatography—Low resolution (quadrupole) mass spectrometry by using electrospray ionization and atmospheric pressure chemical ionization interfaces. J. Chromatogr. A 2017, 1509, 69-82. [CrossRef] [PubMed]

26. Morowvat, M.H.; Ghasemi, Y. Cell Growth, Lipid Production and Productivity in Photosynthetic Micro-alga Chlorella vulgaris under Different Nitrogen Concentrations and Culture Media Replacement. RecentPat. Food Nutr. Agric. 2018, 9, 142-151.

27. Brahamsha, B. A genetic manipulation system for oceanic cyanobacteria of the genus Synechococcus. Appl. Environ. Microbiol. 1996, 62, 1747-1751. [CrossRef]

28. Singh, P.; Gupta, S.K.; Guldhe, A.; Rawat, I.; Bux, F. Microalgae Isolation and Basic Culturing Techniques. In Handbook of Marine Microalgae; Elsevier: Amsterdam, The Netherlands, 2015; pp. 43-54; ISBN 978-0-12-800776-1.

29. Andersen, R.A. (Ed.) Algal Culturing Techniques; Academic Press: Cambridge, UK, 2005; ISBN 978-0-12-088426-1.

30. Tischer, R.G. Pure Culture of Anabaena flos-aquae A-37. Nature 1965, 205, 419-420. [CrossRef]

31. Izadpanah, M.; Gheshlaghi, R.; Mahdavi, M.A.; Elkamel, A. Effect of light spectrum on isolation of microalgae from urban wastewater and growth characteristics of subsequent cultivation of the isolated species. Algal Res. 2018, 29, 154-158. [CrossRef]

32. Sakata, T.; Yoshikawa, T.; Maeda, K.; del Castillo, C.S.; Dureza, L.A. Identification of microalgae isolated from green water of tilapia culture ponds in the Philippines. Mem. Fac. Fish. Kagoshima Univ. 2005, 54, $35-44$.

33. Díez, B.; Pedrós-Alió, C.; Marsh, T.L.; Massana, R. Application of Denaturing Gradient Gel Electrophoresis (DGGE) To Study the Diversity of Marine Picoeukaryotic Assemblages and Comparison of DGGE with Other Molecular Techniques. Appl. Environ. Microbiol. 2001, 67, 2942-2951. [CrossRef]

34. Rodríguez-Ferri, E.; Badiola-Díez, J.J.; Cepeda-Sáez, A.; Domínguez-Rodríguez, L.; Otero-Carballeira, A.; Zurera-Cosano, G. Grupo de trabajo. Informe del ComitéCientífico de la Agencia Española de 
SeguridadAlimentaria y Nutrición (AESAN) sobre la evisceración de loslagomorfos. RevistaComitéCientífico AESAN 2009, 9, 31-38.

35. Folch, J.; Lees, M.; Stanley, G.S. A simple method for the isolation and purification of total lipides from animal tissues. J. Biol. Chem. 1957, 226, 497-509.

36. Bligh, E.G.; Dyer, W.J. A rapid method of total lipid extraction and purification. Can. J. Biochem. Physiol. 1959, 37, 911-917. [CrossRef]

37. Li, Y.; Horsman, M.; Wang, B.; Wu, N.; Lan, C.Q. Effects of nitrogen sources on cell growth and lipid accumulation of green alga Neochlorisoleoabundans. Appl. Microbiol. Biotechnol. 2008, 81, 629-636. [CrossRef]

38. Montgomery, D.C. Design and Analysis of Experiments; John Wiley \& Sons: Hoboken, NJ, USA, 2017; ISBN 1-119-11347-4.

39. Egge, J.K. Are diatoms poor competitors at low phosphate concentrations? J. Mar. Syst. 1998, 16, 191-198. [CrossRef]

40. Egge, J.K.; Aksnes, D.L. Silicate as regulating nutrient in phytoplankton competition. Mar. Ecol. Prog. Ser. Oldendorf. 1992, 83, 281-289. [CrossRef]

41. Ahlgren, G. Temperature Functions in Biology and Their Application to Algal Growth Constants. Oikos 1987, 49, 177. [CrossRef]

42. Thompson, P.A.; Guo, M.; Harrison, P.J.; Whyte, J.N.C. Effects of variation in temperature. ii. on the fatty acid composition of eight species of marine phytoplankton. J. Phycol. 1992, 28, 488-497. [CrossRef]

43. Stirk, W.A.; Bálint, P.; Tarkowská, D.; Strnad, M.; van Staden, J.; Ördög, V. Endogenous brassinosteroids in microalgae exposed to salt and low temperature stress. Eur. J. Phycol. 2018, 53, 273-279. [CrossRef]

44. Kang, E.J.; Kim, K.Y. Effects of future climate conditions on photosynthesis and biochemical component of Ulva pertusa (Chlorophyta). Algae 2016, 31, 49-59. [CrossRef]

45. El Arroussi, H.; Benhima, R.; El Mernissi, N.; Bouhfid, R.; Tilsaghani, C.; Bennis, I.; Wahby, I. Screening of marine microalgae strains from Moroccan coasts for biodiesel production. Renew. Energy. 2017, 113, 1515-1522. [CrossRef]

46. Griffiths, M.J.; Harrison, S.T. Lipid productivity as a key characteristic for choosing algal species for biodiesel production. J. Appl. Phycol. 2009, 21, 493-507. [CrossRef]

47. Rodolfi, L.; ChiniZittelli, G.; Bassi, N.; Padovani, G.; Biondi, N.; Bonini, G.; Tredici, M.R. Microalgae for oil: Strain selection, induction of lipid synthesis and outdoor mass cultivation in a low-cost photobioreactor. Biotechnol. Bioeng. 2009, 102, 100-112. [CrossRef]

48. Haixing, C.; Qian, F.; Yun, H.; Ao, X.; Qiang, L.; Xun, Z. Improvement of microalgae lipid productivity and quality in an ion-exchange-membrane photobioreactor using real municipal wastewater. Int. J. Agric. Biol. Eng. 2017, 10, 97-106.

49. Illman, A.M.; Scragg, A.H.; Shales, S.W. Increase in Chlorella strains calorific values when grown in low nitrogen medium. Enzyme Microb. Technol. 2000, 27, 631-635. [CrossRef]

50. MacDougall, K.M.; McNichol, J.; McGinn, P.J.; O'Leary, S.J.; Melanson, J.E. Triacylglycerol profiling of microalgae strains for biofuel feedstock by liquid chromatography-high-resolution mass spectrometry. Anal. Bioanal. Chem. 2011, 401, 2609-2616. [CrossRef]

51. Alves, E.; Domingues, M.R.M.; Domingues, P. Polar lipids from olives and olive oil: A review on their identification, significance and potential biotechnological applications. Foods 2018, 7, 109. [CrossRef]

52. Hu, Q.; Sommerfeld, M.; Jarvis, E.; Ghirardi, M.; Posewitz, M.; Seibert, M.; Darzins, A. Microalgaltriacylglycerols as feedstocks for biofuel production: Perspectives and advances. Plant J. 2008, 54, 621-639. [CrossRef] [PubMed]

53. Wang, B.; Li, Y.; Wu, N.; Lan, C.Q. $\mathrm{CO}_{2}$ biomitigation using microalgae. Appl. Microbiol. Biotechnol. 2008, 79, 707-718. [CrossRef]

54. Chisti, Y. Biodiesel from microalgae. Biotechnol. Adv. 2007, 25, 294-306. [CrossRef]

Publisher's Note: MDPI stays neutral with regard to jurisdictional claims in published maps and institutional affiliations. 